\title{
UMA (RE)LEITURA DA HISTÓRIA OFICIAL
}

\author{
Marilu Martens de Oliveira
}

\section{Resumo:}

No início dos anos 60 implantou-se, no Brasil, uma ditadura militar da direita, enquanto que a "inteligência" brasileira brasileira pendia para a esquerda.

Anos rebeldes, palavras de ordem, CPC, UNE, CCC, Maria Antônia, PUC, USP, Mackenzie, censura, engajamento, repressão, subversivos, MEC/USAID, sub desenvolvimento, bossa-nova, iê-iê-iê, tropicália - miscelânia que retra ta nosso país num dos períodos mais conturbados de sua história, que de ve ser resgatada e até mesmo "revisada".

A saída para o impasse, para driblar a censura, foi a chamada "linguagem da fresta", usada principalmente nas canções populares. Músicas, filmes, livros (ficcionais ou não), peças teatrais, enfim, a produção cultural desse período mostra um Brasil fragmentado, espoliado, subjugado, calado.

É preciso, pois, que se faça a leitura da verdadeira História, que se reconstrua o passado, num processo que permita repensar o presente e 0 futuro, analisando e discutindo esse material.

Através da análise da produção cultural brasileira das décadas de 60 e 70, é possível efetuar-se um resgate da nossa História, ou melhor, uma "revisão" da História Oficial.

No início dos chamados "anos rebeldes", numa ditadura da direita, observa-se a hegemonia cultural da esquerda ligada à produção ideológica (engajamento de jornalistas, sociólogos, artistas, estudantes, alguns setores do clero). É a fase da "Internacionalização do mercado", segundo o então sociólogo Fernando Henrique Cardoso: o país subdesenvolvido de um lado, e de outro, mecanismos tecnocráticos altamente sofisticados. Como solução surgia uma ampla frente, uma aliança de classes, que provocaria a grande transformação, acabando com os dois brasis (pobres/ricos). O capital estrangeiro e o latifúndio teriam que ser extintos e o poder estaria com o povo, cuja arma seria uma cultura popular, com raízes folclóricas.

A "inteligência" procura uma saída para o impasse, tenta chegar às camadas populares, procura driblar a censura da ditadura, passando a usar a chamada "linguagem da fresta", expressão atribuída por Gilberto Vasconcelos a Caetano Vekloso, embora este tenha dito que sua intenção não fora bem esta ao usá-la (a metáfora da cesta e da fresta era a da cabeça). Mas que, no fundo, era isso mesmo: era dizer algo que não podia ser dito, usando-se alegorias, usandose subterfúgios. Na "Festa imodesta", Caetano presta homenagem ao malandro nacional que - via humor - fala, num momento em que se exige do brasileiro o "discurso sem voz". Outro exemplo é a música "Cálice"/Cale-se, na qual houve iconização, como bem observa, no seu belíssimo Desenho Mágico - poesia e política em Chico Buarque, Adelia Bezerra de Meneses, sendo calado pela censura, numa apresentação, a então, unanimidade nacional, Chico Buarque de Holanda, que chegou a usar os nomes de Julinho da Adelaide e Leonel de Paiva para driblar os censores.

Músicas como "Cordão", "Samba de Orly", "Acorda Amor", "Viola Enluarada", "Aroeira", "Louvação", "Ponteio", "Disparada", "A Estrada e o Violeiro" e "Apesar de Você" fazem parte de uma proposta renovadora, desnudando a realidade e quebrando a magia proposta pela Bossa-Nova da canção "Light" da moça - amor - mar - violão, da pobreza poética, em que a favela é prateda pelo luar. O triste cotidiano é revelado, surgindo as canções que, embora denunciem e protestem, são chamadas por Walnice Galvão em seu ensaio "MPB" - uma análise ideológica de 
escapistas. Ela mostra que a História não é assumida, que há uma evasão à responsabilidade pessoal (tanto do cantor-autor como dos ouvintes), e que a desculpa é o "dia que virá" e o "mito da canção que consola" (canto para anunciar o dia que virá", canto para me consolar"). Todos se eximem da responsabilidade social, não se colocando como sujeitos da História e, apesar das palavras de ordem, permanecendo um tanto apáticos, aguardando a chegada da entidade mítica - o dia que virá - que resolverá todos os problemas. O texto é reduzido a mero veículo para a mensagem política e a canção, a um simples consolo. Logo, canções que parecem politizadas esvaziam tudo. Mesmo Vandré, que é mais incisivo - "Quem sabe faz a hora, não espera acontecer" - não resolve o problema, pois continua "caminhando e cantando". É a festa da chamada esquerda festiva intelectualizada, que se limita ao oba-oba dos festivais e da denúncia, sem passar à práxis, com raríssimas exceções. E cantando e caminhando para o Sul vêm os tropicalistas Gilberto Gil, Caetano Veloso, Tom Zé, Capinam e o anjo "gauche" Torquato Neto. Para o crítico José Ramos Tinhorão eles não tinham uma proposta política, eram oportunistas querendo fazer sucesso. Mas o que se percebe é que o baianos eram diferentes: destruíram o pensamento linear, usando a "bricollage", a linguagem fragmentada, para mostrar o imnpasse brasileiro. Subliminarmente realizam uma crítica sócio-política-estética, anárquica, paródica, kitsch. É a geléia real, o desbunde, que mostra o Brasil de contrastes. Convivem o arcaico e o moderno, o urbano e o rural, o subdesenvolvimento e o progresso tecnológico, o monumento (Brasília) e a palhoça, a bossa, o samba e o iê-iê-iê. É a aproximação com os concretistas e com a antropofagia, a"retomada oswaldiana", via dessacralizaçãode todos os ídolos, de todos os gêneros, de todos os valores. "Alegria, alegria", "Tropicália" e "Domingo no Parque" representam bem esse tropicalismo brasileiro. Caetano, contradizendo Tinhorão, continua seu trabalho (não é uma estrela meteórica), rompe a barreira entre o popular e o erudito, conversa com Bilac e Pessoa, entre outros. É a "antena da raça", de que fala Pound.

E é esse Brasil fragmentado, espoliado, calado, subjugado, americanizado que aparece em filmes, como "Eles não usam black-tie", "Dedé Mamata", "Pra Frente, Brasil", "Cinco vezes Favela", "Deus e o Diabo na Terra do Sol", "Terra em transe", e, numa visão mais próxima, em "Bye, Bye, Brasil". Quem são os protagonistas? Quem é o antagonista? Qual o clímax de "Pra frente, Brasil"? É o desfile dos jogadores brasileiros com a taça Jules Rimet, sendo recebidos pelo Presidente Médici, enquantos nos porões da ditadura, brasileiros eram torturados no pau-dearara?! O espaço muda, mas as personagens e os discursos são os mesmos. O que dizer de "História Oficial", filme argentino, obra aberta e circular, que denuncia o drama das mães, das "loucas da Plaza de Maio", e o desconhecimento ou a aceitação da História real? E na mesma linha há "Missing - desaparecido", mostrando a queda de Allende, no Chile; "Chove sobre Santiago", em que a tradução, talvez propositadamente é mal feita, e a legenda não mostra o que é dito: o envolvimento brasileiro e americano na derrubada do governo socialista chileno. Podem ser vistos também "El Salvador - martírio de um povo", o recente "Morango e Chocolate", cubano, e tantos outros, que denunciam as perseguições, os crimes, os mortos, os desaparecidos, os guerreiros anônimos de uma América Latina emudecida, silenciada por militares ensandecidos, que jogavam no mar e na floresta os subversivos (num jargão da época), os "Pedros Nadies", as vozes discordantes que precisavam ser caladas. E é através do romance social, que teve enormes imbricações com o jornalismo, que acontecimentos e informações que a censura não tolerava na TV, em rádios e jornais, apareceram na literatura. Era ficção, logo, aceitável. Assim aconteceu com Incidente em Antares, magistral criação de Érico Veríssimo, que conseguiu escapar pela fresta, empurrada pelo renome do autor e pela desculpa de que era irreal, obra fantástica, tão comum na literatura latino-americana, e com Quarup, de Antonio Callado, em que a História e ficção digladiavam-se para mostrar com imparcialidade a realidade brasileira, dos anos 50 até o período da ditadura provocada pela revolução de 1964, passando pelo crivo analítico do autor - ficcionista/jornalista, que traça um painel histórico-social, mostrando a luta de Pedro Nando contra o regime militar.

Já na linha do romance documentário(ou jornalismo) aparece 1968 - o ano que não terminou, de Zuenir Ventura, sobre o auge da repressão - o Al-5 e suas conseqüências, destacando-se os capítulos sobre a perseguição à peça Rodaviva e seus autores, e aos músicos Gil e Caetano, que tiveram suas cabeças raspadas, sendo confinados até os "caracóis dos seus cabelos" crescerem(ver canção de Roberto Carlos) e depois se auto-exilaram em Londres, Suas músicas "London-London" e "Aquele abraço" retratam esse momento doloroso.

Judith Patarra escreve lara - reportagem biográfica, retrato sensível da jovem estudante de Psicologia, que sai da USP para a guerrilha urbana, encontrando seu grande amor, Lamarca, que por sua vez é protagonista do livro e filme: Lamarca, o capitão da guerrilha. Alfredo Sirkis, carioca, estudante secundarista, envolvido em seqüestros, relata suas experiências em Os Carbonários, Roleta Chilena e O Corredor Polonês. Outra publicação - Brasil: nunca mais choca por ser extremamente bem documentada e ter o aval de grupos católicos e pessoas envolvidas com os direitos humanos. São relatos que vão "além da imaginação", tal a barbárie cometida contra brasileiros, na sua maioria jovens, comprometidos ideologicamente com a esquerda. Fernando Gabeira, o deputado verde, em O que é isso, companheiro?, mescla jornalismo e ficção, história e literatura, documento e confissão, resgatando um momento decisivo para os brasileiros. Gabeira exila-se, trabalha, torna-se "operário do primeiro mundo", questionando-se, interrogando o que foi e o "devir". Seu depoimento, para Davi Arrigucci Jr., aproxima-se do romance 
de formação ou de aprendizagem, sendo chamado de "Memórias do Cárcere destes dias", numa alusão a obra de Graciliano.

Mais recentemente, Fernando Morais com Olga e Chatô - o rei do Brasil continua a questionar a História que aprendemos nos bancos escolares, mostrando que - a exemplo do filme do mesmo nome - a História Oficial é uma, que não a mesma que vivemos, e é preciso que se faça a leitura da verdadeira História, que se reconstrua o,passado, num processo que permita repensar o presente e o futuro.

\section{BIBLIOGRAFIA}

ARNS, D. Paulo Evaristo. Brasil: Nunca mais. Petreopolis: Vozes, 1985.

ARRIGUCCI JR., Davi. Enigma e Comentário. São Paulo: Companhia das Letras, 1987.

BERNARDET, Jean-Claude; RAMOS, Alcides F.R. Cinema e História do Brasil. São Paulo: Contexto, 1988. COUTO, José Geraldo et alii. Coletânia Lições com Cinema. São Paulo. FDE/Diretoria Técnica, 1993.

FAVARETO, Celso F. Tropicália: Alegoria, Alegria. São paulo: Cairós, 1979.

FRANCO, Marília da Silva et alii. Coletânia Lições com Cinema. São Paulo: FDE/Diretoria Técnica, 1993.

GABEIRA, Fernando. $O$ que é isso, companheiro. 18 ed. Rio de Janeiro: Codecri, 1980.

GALVÃO, Walnice Nogueira. "MPB: Uma Análise Ideológica". In Saco de Gatos. São Paulo: Livraria Duas

Cidades, 1976.

GORENDER, Jacob. Combate nas Trevas - A esquerda brasileira: das ilusões perdidas à luta armada. 3. ed.

São Paulo: Ática, 1987.

MENESES, Adélia Bezerra de. Desenho Mágico: poesia e política em Chico Buarque. São Paulo: Hucitec, 1982.

MIRANDA, Oldack; JOSÉ, Emiliano. Lamarca, o capitão da guerrilha. 6. ed. São Paulo: Global, 1980.

MORAIS, Fernando. Olga. 7 ed. São Paulo: Alfa-Ômega, 1986.

PALMÉRIO, Dória et alii. A Guerrilha do Araguaia. São Paulo: Alfa-Ômega, 1978.

PATARRA, Judith L. lara. Reportagem biográfica. Rio de Janeiro: Rosa do Tempo, 1992.

SCHWARZ, Roberto. "Cultura e Política - 1964/1969". O Pai de Família e Outros Estudos. Rio de Janeiro: Paz e Terra, 1978.

SIRKIS, Alfredo. Os Carbonários - Memorias da Guerrilha Perdida. 7. ed. São Paulo: Global, 1981.

SODRÉ, Nelson Werneck. Vida e Morte da Ditadura - 20 anos de autoritarismo no Brasil. Petrópolis: Vozes, 1984.

TINHORÃO, José Ramos. Pequena História da Música Popular: da Modinha ao Tropicalismo. 5. ed. São

Paulo: Art Editora, 1986.

VASCONCELLOS, GIlberto. Música Popular: de olho na fresta. Rio de Janeiro: Graad, 1977.

VENTURA, Zuenir. 1968 - O ano que não terminou. 11. ed. Rio de Janeiro: Nova Fronteira, 1988.

ZíLIO, Carlos. "Artes Plásticas: Da Antropofagia à Tropicália". In: O Nacional e o Popular na Cultura

Brasileira. São Paulo: Brasiliense, 1982. 